\title{
FORMULASI PEWARNA RAMBUT DARI BIJI PEPAYA (Carica papaya L.) DALAM BENTUK SEDIAAN GEL
}

\author{
Ira Adiyati Rum ${ }^{1 *}$, Maria Ulfha ${ }^{2}$, Dolih Ghazali ${ }^{3}$ \\ 1. Sekolah Tinggi Farmasi Bandung, Bandung-Indonesia \\ 2. Sekolah Tinggi Farmasi Bandung, Bandung-Indonesia \\ 3. Sekolah Tinggi Farmasi Bandung, Bandung-Indonesia
}

*Korespondensi: Ira Adiyati Rum | Sekolah Tinggi Farmasi Bandung | ira.adiyati@ stfb.ac.id

\begin{abstract}
Abstrak
Pendahuluan: Sediaan pewarna rambut adalah kosmetika yang digunakan dalam tata rias rambut untuk mewarnai rambut, baik untuk mengembalikan warna rambut asli atau mengubah warna rambut asli menjadi warna baru. Tujuan penelitian ini untuk mengetahui pembuatan pewarna rambut alami dari biji papaya dengan penambahan bahan pembangkit warna piragolol, juga untuk mengetahui konsentrasi ekstrak biji pepaya yang menghasilkan warna terbaik.

Metode: Metode dilakukan dengan maserasi, pengujian ini dengan berbagai konsentrasi ekstrak biji papaya yaitu 3\%, $5 \%$ dan $8 \%$ masing-masing dicampur dengan formula gel yang mengandung HPMC 2,5\%, gliserin 6,25\%, propilenglikol $15 \%$, dmdm hidantoin $0,6 \%$ sebagai pengawet antimikroba dan piragolol $1 \%$. Formula sediaan yang telah dihasilkan dilakukan uji stabilitas fisik meliputi pengamatan secara visual, $\mathrm{pH}$, viskositas, stabilitas warna terhadap pencucian, stabilitas warna terhadap sinar matahari, uji daya sebar, dan uji biologis (iritasi).

Hasil: Hasil penelitian menujukkan bahwa warna rambut yang dihasilkan dipengaruhi oleh konsentrasi ekstrak biji pepaya dan waktu perendaman, yaitu semakin tinggi konsentrasi ekstrak dan semakin lama waktu perendaman akan menghasilkan warna yang semakin gelap dari pirang sampai dengan pirang kecoklatan.

Kesimpulan: Kesimpulan dari penelitian ini adalah ekstrak biji pepaya dapat diformulasikan sebagai pewarna rambut. Konsentrasi ekstrak biji pepaya $8 \%$ memberikan warna terbaik yaitu pirang kecoklatan, $\mathrm{pH}$ masih sesuai persyaratan $\mathrm{pH}$ gel untuk kulit yaitu 5,0-10. Viskositas mengalami perubahan turun naik, perubahan ini kemungkinan disebabkan oleh faktor yang berpengaruh selama penyimpanan. Stabilitas terhadap pencucian, sinar matahari langsung, daya sebar dan tidak menimbulkan reaksi iritasi pada kulit.
\end{abstract}

Kata Kunci : Biji pepaya (Carica papaya L), Piragolol, Gel, Pewarna rambut.

Diterima 02 Februari 2019; Accepted 30 Juni 2019

\section{PENDAHULUAN}

Perkembangan ilmu farmasi akhir-akhir ini menunjukkan adanya peningkatan penggunaan bahan alami sebagai dasar dari suatu sediaan kosmetik. Masyarakat kini lebih memilih produk yang mengandung bahan alami untuk digunakan dengan tujuan pengobatan maupun perawatan tubuh karena faktor keamanan dan efek samping yang relatif lebih kecil dibandingkan zat kimiawi.

Salah satu jenis sediaan kosmetik yang digemari ialah pewarna rambut, karena rambut tumbuh hampir di semua bagian tubuh, kecuali telapak tangan dan kaki, kelopak mata, serta bibir. Salah satu bagian tubuh yang ditumbuhi rambut ialah kepala. Rambut adalah sesuatu yang tumbuh dari lapisan dermis dan melalui saluran folikel rambut ke luar dari kulit. Bagian rambut yang keluar dari kulit dinamakan batang rambut (Tranggono dan Latifh, 2007).

Rambut dikenal sejak zaman dahulu dengan julukan "mahkota" bagi wanita. Tetapi di zaman yang sudah maju seperti sekarang, julukan tersebut tidak lagi tertuju hanya kepada kaum wanita, namun juga untuk pria. Peranan rambut sangat penting untuk diperhatikan karena rambut bukan hanya sebagai pelindung kepala. Tetapi juga pertama sebagai pelindung terhadap rangsangan fisik seperti panas, dingin, kelembaban dan sinar. Kedua sebagai pelindung terhadap rangsangan mekanik seperti pukulan, gosokan dan tekanan serta ketiga sebagai pelindung terhadap rangsangan kimia seperti berbagai zat kimia dan keringat (Tranggono dan Latifah 2007; Ditjen POM 1985).

Warna rambut ditentukan oleh pigmen melanin di dalam rambut yang ada dalam lapisan korteks. Bahan asal pigmen melanin adalah melanosit yang berada dalam umbi rambut. Melanosit adalah sel-sel yang menghasilkan pigmen (zat warna) yang menyebabkan rambut asli dapat memiliki bermacam - macam warna (Bariqina dan Ideawati, 2001). 
Urutan pigmen yang menentukan warna rambut dari yang paling terang sampai yang paling gelap ialah pirang, merah, coklat muda, coklat tua dan hitam.

- Rambut pirang mempunyai pigmen campuran warna merah dan kuning.

- Rambut merah mengandung campuran pigmen warna merah dan pigmen warna hitam.

- Rambut coklat muda mengandung pigmen-pigmen warna merah, coklat dan hitam.

- Rambut coklat tua mengandung lebih banyak pigmen warna hitam dari pada rambut coklat muda.

- Rambut hitam hanya mengandung pigmen warna hitam (Tranggono dan latifah, 2007).

Bila sudah mencapai usia lanjut, warna rambut berubah menjadi putih dan ini sering kurang disukai keberadaannya (Wasitaatmadja, 1997). Timbulnya uban biasanya terkait dengan usia dan kemampuan tubuh untuk memproduksi melamin, sehingga biasanya uban mulai tumbuh pada usia 45 tahun keatas. Akan tetapi uban dapat pula muncul pada usia yang lebih muda karena adanya faktor genetis. Faktor penyebab rambut beruban biasanya disebabkan oleh faktor gizi, metabolisme, zat kimiawi, faktor keturunan dan lain-lain (Kusumadewi, 2003).

Uban merupakan salah satu masalah rambut yang mempengaruhi seseorang. Salah satu cara untuk membuat rambut menarik ialah dengan mewarnai rambut. Mewarnai rambut tidak hanya merubah warna rambut dari putih (uban) menjadi hitam atau warna yang yang dikehendaki tetapi juga untuk fashion. Mewarnai rambut bagi seseorang sudah menjadi kebutuhan agar dalam setiap penampilannya lebih nenarik. Warna rambut dapat diubah-ubah secara buatan dengan menggunakan cat rambut, di Indonesia disebut juga dengan semir rambut (Tranggono dan Latifah, 2007)

Sediaan pewarna rambut adalah sediaan kosmetika yang digunakan dalam tatarias rambut untuk mewarnai rambut, baik untuk mengembalikan warna rambut asalnya atau warna lain. Pewarnaan rambut dapat dilakukan dengan berbagai cara, menggunakan berbagai jenis zat warna, baik zat warna alami maupun sintetik (Ditjen POM, 1985).

Sediaan pewarna rambut yang sekarang ini beredar di masyarakat sebagian besar menggunakan bahan pewarna sintetik. Pewarna sintetik diperbolehkan penggunaannya tetapi dengan batas kadar tertentu, sedangkan jika bahan pewarna sintetik digunakan secara terus menerus dalam jangka waktu yang lama dan dengan kadar yang berlebihan maka akan dapat menimbulkan berbagai macam masalah kesehatan seperti kerusakan jaringan otak, iritasi kulit, kerusakan organ tertentu seperti ginjal, hati, gangguan syaraf, teratogenik, karsinogenik dan gangguan mutagenik (Depkes RI,1985).

Salah satu bahan alam yang digunakan sebagai pewarna rambut ialah biji pepaya yang mempunyai kandungan zat pewarna glucoside saccarine dan alkaloid carpaine (Jetts,2012. Biji pepaya digunakan sebagai pewarna rambut alami karena berasal dari tumbuhan dan mempunyai sifat untuk menyehatkan rambut. Biji pepaya yang digunakan dalam bentuk gel.

\section{METODE}

Metodologi penelitian ini adalah eksperimental. Penelitian ini meliputi penyiapan simplisia, determinasi simplisia, pembuatan ekstrak, skrining fitokimia ekstrak, pembuatan formulasi sediaan gel yang ditambahkan ekstrak biji pepaya serta konsentrasinya, pengujian stabilitas fisik sediaan, pengujian efektivitas pewarnaan dan pengujian iritasi sediaan gel pewarna rambut. Penyiapan simplisia yang digunakan penelitian ini adalah biji pepaya (Carica papaya), untuk mengetahui kebenaran tumbuhan uji yang digunakan maka dilakukan determinasi tanaman dengan cara membandingkan bahan yang dideterminasi dengan pustaka.

Pembuatan ekstrak biji pepaya dilakukan dengan cara maserasi dengan pelarut Etanol $96 \%$ selama $3 \mathrm{x}$ 24 jam, hasil ekstraksi diuapkan dengan rotary evaporator sampai diperoleh ekstrak yang kental. Untuk mengetahui senyawa yang terdapat pada biji pepaya tersebut, maka dilakukan uji skrining fitokimia meliputi pemerikasaan senyawa alkaloid, flavonoid, tannin, saponin, steroid dan terpenoid. Pembuatan formulasi hasil ekstraksi biji pepaya dengan variasi konsentrasi yaitu 3\%, 5\%, 8\% dicampur dengan formulasi gel. Untuk mengetahui berapa \% konsentarasi yang menghasilkan warna terbaik pada rambut.

Pengujian stabilitas fisik sediaan dilakukan dengan pengamatan organoleptis, pengukuran $\mathrm{pH}$ dan viskositas selama 28 hari penyimpanan ,suhu penyimpanan 25 Celcius. Pengujian efektivitas pewarna sediaan gel dilakukan terhadap sediaan gel pewarna rambut dengan konsentrasi terkecil dan terbesar. Untuk mengetahui apakah sediaan gel pewarna rambut memberikan perubahan atau efek pewarnaan pada rambut. 
Pengujian iritasi sediaan gel pewarna rambut dengan menggunakan tekhnik uji tempel terbuka dengan konsentrasi zat warna terbesar dan diamati apakah menimbulkan rasa gatal dan timbulnya warna karena terjadi iritasi pada kulit atau tidak.

\section{HASIL}

\section{Pembuatan Ekstrak Biji Pepaya}

Biji pepaya diekstraksi dengan menggunakan cara dingin yaitu dengan metode maserasi dengan menggunakan pelarut etanol 95\% (Gozali dkk, 2009). .Ekstrak biji pepaya diperoleh dari melarutkan $2 \mathrm{~kg}$ biji pepaya dengan pelarut etanol $95 \%$ sebanyak 34 liter, sehingga diperoleh ekstrak sebanyak 135 gram. Ekstrak kental biji pepaya dapat dilihat pada gambar dibawah ini:

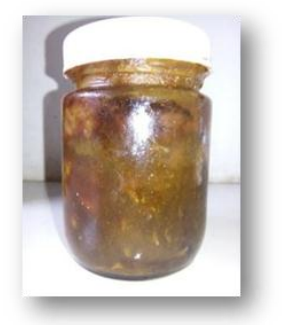

Gambar 1. Ekstrak biji pepaya menghasilkan warna coklat

Selanjutnya dilakukan skrining fitokimia pada ekstrak biji pepaya untuk mengetahui golongan senyawa yang terkandung didalamnya. Hasil skrining fitokimia ekstrak biji pepaya (Carica papaya L.) ialah alkaloid, tanin, saponin, triterpenoid/steroid dan fenol.

\section{Pembuatan Sediaan Gel dengan Variasi Konsentrasi Ekstrak Biji Pepaya (Carica papaya L.) Optimasi Sediaan Gel}

Dilakukan optimasi bertujuan untuk mengetahui apakah bahan-bahan formulasi pada pembuatan sediaan gel dapat dibuat dan untuk mengetahui formulasi basis gel mana ya cocok dibuat dengan variasi konsentrasi basis HPMC yaitu 1,5\%, 2\%, 2,5\%, 3\%, 3,5\% dan 4\% tanpa penambahan ekstrak. Metode optimasi dengan menggunakan desain Simple Lattice. Variasi basis dilakukan untuk mengetahui dan melihat pengaruh basis terhadap mutu sediaan gel dan membandingkan stabilitas serta formula mana yang terbaik, kemudian didapatkan basis gel yang terbaik yaitu 2,5\%, selanjutnya ditambahkan ekstrak biji pepaya dengan 3 konsentrasi yaitu 3\%, 5\% dan $8 \%$ (Tabel 1).

\section{Uji Stabilitas (uji freeze-thaw)}

Evaluasi stabilitas fisik dengan metode freeze thaw ditentukan dengan menyimpan sediaan tidak kurang dari 48 jam pada suhu $4^{\circ} \mathrm{C}$.Setelah 48 jam, dilihat jika adanya pemisahan fase. Kemudian disimpan pada suhu $40^{\circ} \mathrm{C}$ selama 48 jam, kemudian dilihat terjadinya pemisahan fase (Gozali, D). Pengujian dilakukan selama 4 siklus.

Uji stabilitas dengan menggunakan metode freeze thaw merupakan salah satu cara untuk menguji kestabilan sediaan pewarna rambut (Djajadisastra, 2004). Pengujian organoleptis pada uji stabilitas (freeze thaw) terjadi perubahan warna, perubahan homogenitas pada siklus ke-3 dan ke-4 dan aroma yang kuat pada siklus ke-4.

\section{Pengukuran $\mathrm{pH}$}

Derajat keasaman $(\mathrm{pH})$ merupakan salah satu parameter pengujian dalam analisis produk kosmetik, yang dimana $\mathrm{pH}$ dari kosmetik dapat mempengaruhi daya absorbsi kulit.

Tabel 1. Optimasi Sediaan Gel

\begin{tabular}{cccccc}
\hline \multirow{2}{*}{ No. } & \multirow{2}{*}{ Komposisi } & F- & F1 & F2 & F3 \\
\hline 1. & HPMC & 2,5 & 2.5 & 2,5 & 2,5 \\
2. & Gliserin & 6,25 & 6,25 & 6,25 & 6,25 \\
\hline
\end{tabular}




\begin{tabular}{cccccc}
\hline 3. & Propilenglikol & 15 & 15 & 15 & 15 \\
4. & Piragolol & 1 & 1 & 1 & 1 \\
5. & DMDM hidantoin & 0,6 & 0,6 & 0,6 & 0,6 \\
6. & Ekstrak biji papaya & 0 & 3 & 5 & 8 \\
7. & AquaDM & Ad 750 ml & Ad 750 ml & Ad 750 ml & Ad 750 ml \\
& Hasil & Bening & Coklat muda & Coklat muda & Coklat muda \\
\hline
\end{tabular}

Keterangan :

F1 = Formula Dengan Konsentrasi Ekstrak Biji Pepaya 3\%.

F2 $=$ Formula Dengan Konsentrasi Ekstrak Biji Pepaya 5\% .

F3 = Formula Dengan Konsentrasi Ekstrak Biji Pepaya 8\%.

Tabel 2. Hasil pengamatan uji stabilitas freeze- thaw

\begin{tabular}{|c|c|c|c|c|c|c|c|c|c|}
\hline \multirow{3}{*}{ Siklus ke- } & \multicolumn{9}{|c|}{ Formulasi } \\
\hline & \multicolumn{3}{|c|}{$3 \%$} & \multicolumn{3}{|c|}{$5 \%$} & \multicolumn{3}{|c|}{$8 \%$} \\
\hline & $\mathbf{W}$ & $\mathbf{A}$ & $\mathbf{H}$ & $\mathbf{W}$ & $\mathbf{A}$ & $\mathbf{H}$ & $\mathbf{W}$ & $\mathbf{A}$ & H \\
\hline 1 & 1 & 1 & 2 & 1 & 1 & 2 & 1 & 1 & 2 \\
\hline 2 & 1 & 1 & 2 & 1 & 1 & 2 & 1 & 1 & 2 \\
\hline 3 & 1 & 2 & 2 & 1 & 2 & 1 & 1 & 2 & 1 \\
\hline 4 & 2 & 3 & 1 & 2 & 3 & 1 & 2 & 3 & 1 \\
\hline
\end{tabular}

Keterangan:

W (Warna) : 0 (Tidak berwarna), 1(Cokelat Muda), 2(Cokelat Kemerahan), 3(Cokelat Kemerahan pekat), 4 (Cokelat tua)

A (Aroma) khas : 1 (Lemah), 2 (Sedang), 3 (Kuat)

H (Homogenitas) : 1 (Tidak Homogen), 2 (Homogen)

Pada tabel diatas menunjukan F+ (Pembanding), F- (Formula gel tanpa ekstrak biji papaya) dan F3 mengalami penurunan $\mathrm{pH}$ tetapi pada $\mathrm{F} 1$ dan $\mathrm{F} 2$ mengalami $\mathrm{pH}$ yang turun naik $\mathrm{pH}$ tetapi masih sesuai persyaratan $\mathrm{pH}$ sediaan kosmetik berkisar antara 4,5-7,5 (Tranggono, 2007).

Sedangkan untuk mengetahui formula yang $\mathrm{pH}$ paling mendekati dengan $\mathrm{F}+$ (Pembanding) dapat dilihat dengan hasil analisis One-Way ANOVA. Sediaan yang paling mendekati formula positif (Pembanding) adalah formula tiga (F3 ) yakni antara pH F3 sebesar 6,22 hingga 6.38.

\section{$\underline{\text { Uji Viskositas }}$}

Viskositas merupakan tolak ukur sifat fisik yang biasa diukur untuk menakar pengaruh kondisi tekanan pada gel dan dapat dijadikan sebagai parameter untuk menunjukan kestabilan produk kosmetik selama penyimpanan. Pengujian ini dilakukan dengan menggunakan alat Viskometer Brookfield dengan spindle 7 dengan kecepatan $50 \mathrm{rpm}$.

Pengujian viskositas bertujuan untuk mengukur nilai kekentalan suatu zat atau sediaan. Semakin tinggi nilai viskositasnya maka semakin tinggi kekentalan zat tersebut. Pada perhitungan data viskositas sediaan menggunakan uji statistika ANOVA yang menunjukan terdapat perbedaan $(\mathrm{p}<0,05)$. Untuk mengetahui formula yang viskositasnya paling mendekati formula positif (Pembanding) dapat dilihat dengan hasil analisis One-Way ANOVA. Sediaan yang paling mendekati kontrol positif (pembanding) adalah formula tiga (F3) pada viskositas dengan kecepatan $50 \mathrm{rpm}$, yakni viskositas sebesar $20.820 \mathrm{cP}$ (sentipoise) hingga $28.207 \mathrm{cP}$.

\section{Uji Daya Sebar}

Hasil pengukuran daya sebar sediaan gel pewarna rambut dengan variasi konsentrasi ekstrak biji pepaya (Carica papaya L.) selama waktu penyimpanan. Pada uji daya sebar ini diberikan beban diatasnya sebesar 150 gram, kemudian diukur diameternya selang 1 menit. Pengujian ini dilakukan dari minggu ke-1 sampai minggu ke-4. Pengujian daya sebar bertujuan untuk mengetahui penyebaran gel pada sediaan rambut. Penyebaran gel yang baik yaitu antara 5-7 cm (Garg et al., 2002). Pengujian daya sebar sediaan menggunakan uji statistika ANOVA yang menunjukan ada perbedaan yang bermakna $(\mathrm{p}<0,05)$. 


\section{Evaluasi Pengamatan Efektivitas, Stabilitas dan Keamanan terhadap Rambut.}

Hasil Pengamatan secara Visual

1. Hasil Pengamatan Efektivitas (Tabel 3).

2. Pengaruh Konsentrasi sediaan gel dari ekstrak biji pepaya dalam pemberian warna terhadap rambut putih.

Variasi konsentrasi ekstrak biji dapat memberikan perbedaan warna rambut putih yang dihasilkan dari proses perendaman dalam waktu yang sama. Perbedaan warna rambut putih tersebut dapat dilihat pada Gambar 2. Hasil pewarnaan pada F1 (konsentrasi ekstrak biji pepaya 3\%), pewarnaan pada F2 (konsentrasi ekstrak biji pepaya 5\%) dan pewarnaan pada F3 (konsentrasi ekstrak biji pepaya 8\%) memberikan warna coklat kemerahan dari rambut putih (uban).

Tabel 3. Hasil pengamatan efektivitas pewarnaan sediaan gel pewarna rambut dari biji pepaya (Carica papaya $L$.) selama waktu penyimpanan

\begin{tabular}{cccccc}
\hline \multirow{2}{*}{ Sediaan } & \multicolumn{4}{c}{ Efektivitas pewarnaan } & F2 \\
\hline \hline S1 & Hitam & Tidak berwarna & Coklat muda & Coklat muda & Coklat muda \\
S28 & Hitam & Tidak berwarna & $\begin{array}{c}\text { Coklat } \\
\text { kemerahan }\end{array}$ & $\begin{array}{c}\text { Coklat } \\
\text { kemerahan }\end{array}$ & $\begin{array}{c}\text { Coklat } \\
\text { kemerahan }\end{array}$ \\
\hline
\end{tabular}

\section{Keterangan :}

F- = Formula Gel Tanpa Ekstrak Biji Papaya.

$\mathrm{F}+=$ Pembanding Gel Dipasaran (Bigen).

F1 $=$ Formula Dengan Konsentrasi Ekstrak Biji Pepaya 3\%.

F2 $=$ Formula Dengan Konsentrasi Ekstrak Biji Pepaya 5\% .

F3 = Formula Dengan Konsentrasi Ekstrak Biji Pepaya 8\%.

$\mathrm{S} 1=$ Sediaan sehari setelah pembuatan.

S28 = Sediaan setelah 28 hari.

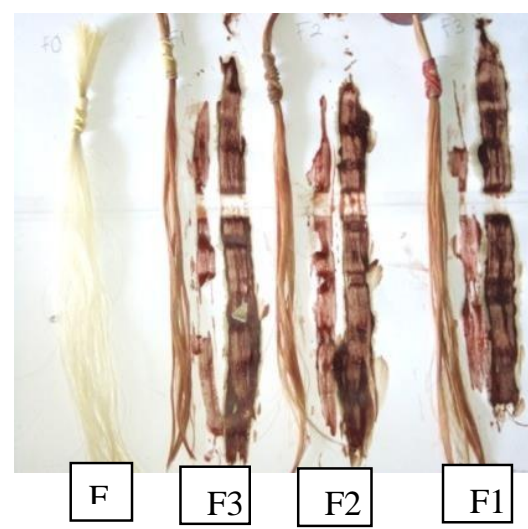

Gambar 2. Pengaruh konsentrasi ekstrak pepaya biji terhadap perubahan warna rambut putih dengan lama

\section{Keterangan :}

perendaman 4 jam.

F0 = Rambut putih blanko

$\mathrm{F} 1=$ Rambut putih dengan konsentrasi ekstrak biji pepaya 3\%, HPMC 2,5\%, gliserin 6,25\%, propilenglikol 15\%, DMDM hidantoin $0,6 \%$ dan piragolol $1 \%$.

F2 = Formula dengan konsentrasi ekstrak biji pepaya 5\%, HPMC 2,5\%, gliserin 6,25\%, propilenglikol 15\%, DMDM hidantoin $0,6 \%$ dan piragolol $1 \%$.

F3 = Formula dengan konsentrasi ekstrak biji pepaya 8\%, HPMC 2,5\%, gliserin 6,25\%, propilenglikol 15\%, DMDM hidantoin $0,6 \%$ dan piragolol $1 \%$.

3. Pengaruh waktu perendaman terhadap hasil pewarnaan rambut

Dari hasil pengamatan terhadap percobaan yang telah dilakukan, diketahui bahwa lamanya waktu perendaman mempengaruhi hasil pewarnaan rambut putih. Dari hasil pengamatan lama perendaman yang 
dilakukan selama 4 jam diperoleh hasil pewarnaan rambut yang optimal. Pewarnaan rambut ini terjadi secara bertahap, sedikit demi sedikit mengubah warna rambut yang putih menjadi warna coklat kemerahan. Pengamatan secara visual terhadap hasil percobaan yang dilakukan diperoleh formula yang menghasilkan perubahan warna paling jelas yang mengarah kepada warna coklat kemerahan yaitu formula 3 (tiga) yang terdiri dari konsentrasi biji pepaya (Carica papaya L.) paling besar yaitu 8\%. Kemudian formula 3 inilah kemudian digunakan untuk uji evaluasi selanjutnya.

\section{Stabilitas warna terhadap pencucian}

Berdasarkan uji stabilitas warna terhadap pencucian diperoleh hasil bahwa tidak terjadi perubahan warna rambut setelah sepuluh kali pencucian .

Stabilitas warna terhadap sinar matahari

Warna ditentukan kestabilannya dengan memaparkan rambut 5 jam dibawah sinar matahari. Ketika rambut terkena sinar matahari langsung warnanya sedikit berubah, hal ini disebabkan sifat dari piragolol yang apabila terkena cahaya akan teroksidasi sehingga warna rambut akan lebih terang dari warna sebelumnya.

\section{Uji Biologis (Uji iritasi)}

Sediaan pewarna rambut yang hendak dipasarkan untuk konsumen harus diberikan penandaan yang jelas mengenai cara penggunaan, komposisi dan kadar zat yang digunakan. Selain itu, pada etiket tersebut harus tercantum perlu tidaknya uji iritasi sebelum digunakan. Uji ini dilakukan untuk meyakinkan apakah dalam formulasi sediaaan pewarna rambut terjadi reaksi antara komponen sehingga terbentuk zat yang bersifat iritan atau toksik. Uji ini dilakukan terhadap 20 orang sukarelawan .

Dari grafik diatas menunjukan bahwa formula satu (F1), formula dua (F2) dan formula tiga (F3) yaitu tidak terjadi iritasi, sensasi gatal tidak timbul, sensasi gatal biasa dan kelengketan pun biasa.

\section{Uji Hedonik (Uji kesukaan)}

Uji kesukaan atau hedonik merupakan suatu cara pengujian untuk mengetahui tanggapan pribadi panelis terhadap kesukaan atau ketidaksukaan berdasarkan tingkatnya terhadap suatu produk atau sampel.

Dilakukan uji hedonik terhadap 20 orang sukarelawan menunjukan formula satu (F1) dan formula dua (F2) dari warna, aroma, terktur dan kenyamanan pada sukarelawan lumayan suka dan formula tiga (F3) yaitu warna, aroma, terktur pada sukarelawan lumayan suka sedangkan kenyamannya suka. Dari uji kesukaaan menurut sukarelawan yang paling banyak disukai konsumen yaitu formula 3 (F3) yang terdiri dari ekstrak biji pepaya (Carica papaya L.) $8 \%$, HPMC 2,5\%, gliserin 6,25\%, propilenglikol $15 \%$, piragolol $1 \%$, DMDM hidantoin 0,6\% dan ditambahkan aqua DM (demineralisasi) sampai batas kalibrasi.

\section{PEMBAHASAN}

Evaluasi sediaan gel yang dilakukan terdiri dari pemeriksaan organoleptik, pengukuran $\mathrm{pH}$, viskositas, daya sebar, stabilitas dan uji iritasi. Pemeriksaan organoleptik bertujuan untuk mengamati penampilan fisik dari sediaan ekstrak biji pepaya, baik dari perubahan warna, bau dan homogenitas dari sediaan gel selama waktu penyimpanan. Secara keseluruhan bahwa gel dengan basis gel HPMC dengan variasi konsentrasi ektrak biji pepaya mengalami perubahan warna selama penyimpanan selama 28 hari pada suhu 25 Celsius. Kemungkinan terjadi karena ada penguraian dari bahan-bahan dalam formula gel. Secara organoleptis sediaan gel pewarna rambut dari ekstrak biji pepaya menghasilkan warna coklat muda, ketiga sediaan gel yang dihasilkan berbau khas, dan bentuk yang dihasilkan yaitu semi padat.

Kemudian dilakukan Uji homogenitas.Untuk uji homogenitas masing-masing sediaan gel pewarna rambut tidak ditemukan adanya butiran-butiran kasar yang berarti bahwa sediaan gel yang dihasilkan terdispersi dengan baik dan membentuk masa gel yang sempurna. Pengujian organoleptis pada uji stabilitas (freeze thaw) terjadi perubahan warna, perubahan homogenitas pada siklus ke-3 dan ke-4 dan aroma yang kuat pada siklus ke-4.

Sedangkan untuk mengetahui formula yang $\mathrm{pH}$ paling mendekati dengan $\mathrm{F}+$ (Pembanding) dapat dilihat dengan hasil analisis One-Way ANOVA. Sediaan yang paling mendekati formula positif (Pembanding) adalah formula tiga (F3 ) yakni antara pH F3 sebesar 6,22 hingga 6.38.Untuk mengetahui formula yang 
viskositasnya paling mendekati dengan kontrol positif dapat dilihat dengan hasil analisis One-Way ANOVA. Sediaan yang paling mendekati formula positif (Pembanding) adalah formula tiga.

Diantara 3 formula yang penyebaran paling baik yaitu formula 3 karena hasil pengukurannya memiliki nilai yang paling tinggi yakni $5,40 \mathrm{~cm}$ hingga $5,64 \mathrm{~cm}$, dari nilai daya sebar tersebut menunjukkan bahwa semakin besar konsentrasi ekstrak biji pepaya (Carica papaya L.) maka nilai daya sebarnya semakin tinggi.

Hasil yang didapat pada masing-masing formula masih dalam toleransi untuk penyebaran nilai daya sebar masih masuk dalam sediaan kosmetik antara 5-7 cm. Hasil pengamatan efektivitas sediaaan gel pewarna rambut dari biji pepaya (Carica papaya L.) antara F1, F2 dan F3 selama waktu penyimpanan setelah satu hari pembuatan kemudian disimpan setelah 28 hari mengalami perubahan warna sediaaan dari coklat muda menjadi coklat kemerahan sedangkan kontrol negatif (gel tanpa penambahan ekstrak biji) dan kontrol positif (pembanding) tidak mengalami perubahan warna. Hasil pewarnaan pada F1 (konsentrasi ekstrak biji pepaya 3\%), pewarnaan pada F2 (konsentrasi ekstrak biji pepaya 5\%) dan pewarnaan pada F3 (konsentrasi ekstrak biji pepaya 8\%) memberikan warna coklat kemerahan dari rambut putih (uban).

Berdasarkan uji stabilitas warna terhadap pencucian diperoleh hasil bahwa tidak terjadi perubahan warna rambut setelah sepuluh kali pencucian. Warna ditentukan kestabilannya dengan memaparkan rambut 5 jam dibawah sinar matahari. Ketika rambut terkena sinar matahari langsung warnanya sedikit berubah, hal ini disebabkan sifat dari piragolol yang apabila terkena cahaya akan teroksidasi sehingga warna rambut akan lebih terang dari warna sebelumnya. Dilakukan uji hedonik terhadap 20 orang sukarelawan menunjukan formula satu (F1) dan formula dua (F2) dari warna, aroma, terktur dan kenyamanan pada sukarelawan lumayan suka dan formula tiga (F3) yaitu warna, aroma, terktur pada sukarelawan lumayan suka sedangkan kenyamannya suka. Dari uji kesukaaan menurut sukarelawan yang paling banyak disukai konsumen yaitu formula 3 (F3) yang terdiri dari ekstrak biji pepaya (Carica papaya L.) 8\%, HPMC 2,5\%, gliserin 6,25\%, propilenglikol 15\%, piragolol 1\%, DMDM hidantoin 0,6\% dan ditambahkan aqua DM (demineralisasi) sampai batas kalibrasi.

\section{KESIMPULAN}

Kesimpulan yang didapat:

1) Ekstrak biji pepaya (Carica papaya L.) dapat diformulasikan sebagai sediaan pewarna rambut dalam bentuk gel sehingga dapat memberikan warna pada rambut yaitu warna coklat muda sampai coklat kemerahan sehingga dapat menutupi rambut uban (putih).

2) Formula yang menghasilkan warna terbaik yang menghasilkan perubahan warna yang jelas yaitu formula 3 yang terdiri dari ekstrak biji pepaya (Carica papaya L.) 8\%, HPMC 2,5\%, gliserin 6,25\%, propilenglikol 15\%, pengawet antimikroba yakni DMDM hidantoin 0,6\% dan piragolol $1 \%$ yaitu warna coklat kemerahan.

\section{REFERENSI}

Bariqina, E., dan Ideawati.(2001). Perawatan \& Penataan Rambut. Yogyakarta: Adi Cita Karya Nusa. Hal. $1-4,26-27$.

Departemen Kesehatan RI, 1995, Farmakope Indonesia, edisi IV , Jakarta, 7.

Ditjen POM. (1985). Formularium Kosmetik Indonesia. Jakarta. Depkes. Hal. 86, 206-219.

Garg, A., Aggarwal, D., Garg, S., \& Sigla, A. K., 2002, Spreading of Semisolid Formulation: An Update, Pharmaceutical Technology, September 2002, 84-102, www.pharmacitec.com. Diakses 16 Mei 2014.

Gozali, D., Rusmiati, D., Utama, P. (2009) Formulasi dan uji stabilitas mikremulsi ketokonazol sebagai antijamur Candida abicans dan Tricophyton mentagrophytes. Farmaka, (7 2), 54-67.

Kusumadewi. 2003. Rambut Anda masalah, Perawatan dan Penataannya. Jakarta: Penerbit Gramedia Pustaka Utama.

Retno Iswari Tranggono. 2007. Buku Pegangan Ilmu Pengetahuan Kosmetik. Jakarta : PT Gramedia Pustaka Utama,Anggota IKAPI

Tranggono, R.I.S. Latifah.(2007). Buku Pegangan Ilmu Pengetahuan Kosmetik. Jakarta:Gramedia Pustaka Umum. 33-37. Wasitaatmadja, S. M. (1997). Penuntun Ilmu Kosmetik Medik. Jakarta: Penerbit UI Press. Hal. 28, 59-60, 182-188. 